\title{
DEMOCRATIZAÇÃO DA JURISDIÇÃO CONSTITUCIONAL: UMA ANÁLISE A PARTIR DE PIERRE BOURDIEU ${ }^{1}$
}

\author{
Democratization of constitutional jurisdiction: an analysis from Pierre Bourdieu
}

\author{
José Querino Tavares Neto² \\ Claudia Maria Barbosa ${ }^{3}$
}

\begin{tabular}{|c|c|}
\hline RESUMO & ABSTRACT \\
\hline $\begin{array}{l}\text { O exercício da jurisdição constitucional para a defesa } \\
\text { do Estado Democrático de Direito é questão que } \\
\text { transcende a clássica separação de poderes, alcança } \\
\text { múltiplas perspectivas na visão de poder e encontra em } \\
\text { Pierre Bourdieu um referencial privilegiado para } \\
\text { análise. A jurisdição constitucional brasileira, } \\
\text { especialmente aquela exercida pelo Supremo Tribunal } \\
\text { Federal, justifica-se na defesa da Constituição e } \\
\text { realização do Estado Democrático de Direito. A } \\
\text { personificação/institucionalização do poder que } \\
\text { caracteriza o Estado como um todo e é especialmente } \\
\text { verificada no processo de escolha e nomeação de } \\
\text { Ministros do Supremo Tribunal Federal ameaça, } \\
\text { contudo, a legitimidade do judicial review e, } \\
\text { paradoxalmente, fere o Estado Democrático que é sua } \\
\text { missão defender. Existe solução? Bourdieu } \\
\text { condicionaria tal possibilidade à alteração do habitus } \\
\text { antidemocrático do Supremo Tribunal Federal, que } \\
\text { perpetua e legitima a violência simbólica. As } \\
\text { condições para que essa alteração possa se dar no } \\
\text { campo necessariamente passa pela democratização do } \\
\text { processo de escolha e de tomada de decisão, o que } \\
\text { exige efetiva participação da sociedade e mecanismos } \\
\text { de controle eficazes. }\end{array}$ & $\begin{array}{l}\text { The exercise of judicial review to the defense of the } \\
\text { democratic state of law is a matter that transcends the } \\
\text { classic separation of powers. It reaches multiple } \\
\text { perspectives on power and the analysis provided by } \\
\text { Pierre Bourdieu is a privileged reference. The } \\
\text { Brazilian constitutional jurisdiction, mainly that } \\
\text { exercised by the Supreme Court, finds its justification } \\
\text { in the defense of the Constitution and effectiveness of } \\
\text { the democratic state. The personification } \\
\text { institutionalization of power that characterizes the } \\
\text { State can be also verified at the process of selection } \\
\text { and nomination to the Supreme Court. It threats the } \\
\text { legitimacy of judicial review and, paradoxically, hurts } \\
\text { the democratic state that is her mission defend. Is there } \\
\text { a solution? To Bourdieu it would be conditioned by the } \\
\text { real changes of the undemocratic habitus of the } \\
\text { Supreme Court, which perpetuates and legitimizes the } \\
\text { symbolic violence. The conditions for that this change } \\
\text { may occur in the field involves both the selection of } \\
\text { Ministers procedures and the decision making process. } \\
\text { In both cases, it's required an effective participation of } \\
\text { society and effective control mechanisms over the } \\
\text { power's exercise. }\end{array}$ \\
\hline $\begin{array}{l}\text { Palavras-chave: Judiciário, Constituição, democracia, } \\
\text { poder }\end{array}$ & $\begin{array}{l}\text { Key-words: Judiciary, Constitution, democracy, } \\
\text { power }\end{array}$ \\
\hline
\end{tabular}

\section{INTRODUÇÃO}

Recentemente, muito se comemorou os 20 anos da Constituição Brasileira e sua maior virtude: a cidadania como rasgo principal. De fato, passados quase meio século de sua

\footnotetext{
${ }^{1}$ Pesquisa realizada com apoio do CNJ, projeto CNJ Acadêmico Edital 01/2010.

2 Professor adjunto da Faculdade de Direito da Universidade Federal de Goiás, do Mestrado em Direito da UNAERP, Doutorando em Direito pela PUCPR, com bolsa sanduíche na York University, Canadá e pós-doutor em Direito Constitucional pela Universidade de Coimbra, ambos com bolsa da Capes.

${ }^{3}$ Doutora em Direito pela Universidade Federal de Santa Catarina. Professora Titular de Direito Constitucional da Pontifícia Universidade Católica do Paraná. Professora do Mestrado e Doutorado em Direito da PUCPR. Visting Professor na York University, Canadá, com bolsa da Fundação Araucária/PR.
} 
61

vigência, existem muitas razões de festejo $^{4}$, entre as quais, um visível fortalecimento da democracia e das instituições; maior pluralismo jurídico, político, social; um Judiciário mais atuante e menos refém do poder; a gradual mudança na mentalidade militar; progressiva democratização, transparência e visibilidade do Judiciário e de suas decisões - fruto da constitucionalização dos direitos, mas, especialmente e determinante, da maturação democrática da sociedade, mesmo em um Judiciário ${ }^{5}$ estruturalmente concebido e legitimado durante o regime de 1964; aumento da influência da mídia na formação da opinião pública; maturidade social e democrática da sociedade como um todo, proporcionando uma cidadania mais atuante; o fim das grandes metanarrativas e afirmação da terceira via ${ }^{6}$.

Evidentemente, houve problemas. Não foram poucas as crises políticas e de legitimidade do poder; a extensão normativa e sua pouca efetividade; a desfiguração da Carta Política original proporcionada pelo número excessivo de Emendas Constitucionais, algumas de extensão impressionantes como a EC 45. Um grande risco contudo, foi a constante e crescente subserviência da jurisdição constitucional, notadamente o risco de desvio de finalidade do Pretório Excelso, que pode ser denominado de crise de identidade do STF, mormente em sua variante do poder.

44 Nas comemorações dos 500 anos da descoberta do Brasil, ocasião onde, além das constantes gafes como a tentativa de funcionamento da Nau brasileira, houve uma missa em Porto Seguro de celebração e afirmação cultural de brancos contra os índios e proprietários da terra usurpada pelos portugueses. Não adianta pedir perdão ao índio em uma liturgia branca e de dominador, pois isso é voltar no tempo e reafirmar a colonização novamente.

55 A cúpula do Judiciário em se tratando dos órgãos de natureza recursal e decisória de gestão deriva desse processo advindo do regime de 1964. Essa constatação se evidencia fortemente pela preponderância dos resquícios observados nas decisões judiciais a respeito dos conflitos no campo e na questão da propriedade. Existe uma predominância de individualização do julgamento nestas questões e criminalização dos Movimentos Sociais, o que enfraquece os direitos coletivos. Recorrentemente, retoma-se o certame da criminalização dos movimentos sociais, movimentos indígenas, quilombolas, etc., como a forte reação ensejada, inclusive no Congresso Nacional com a criação de uma CPI mista para investigar o repasse de verbas públicas ao MST, uma vez que a história das sociedades sempre se constituiu na criminalização da pobreza, dos movimentos de trabalhadores, das mulheres (principalmente na questão do aborto), dos quilombolas. Nada de novo numa sociedade concebida e construída sob uma matriz social centrada na propriedade privada que teve na Revolução Francesa e, portanto, nas constituições nacionais, o "coroamento de um longo processo de luta e transformações por que passou a Europa, como a Reforma, a revolução inglesa e a holandesa que fez finalmente da burguesia a senhora do poder civil da sociedade" (MARÉS, 2003, p. 18).

66 A terceira via foi defendida nos anos 90 do século XX, especialmente, por Anthony Giddens, preconizava aproximação entre esquerda e direita por meio de políticas econômicas conservadoras aliadas com uma política social progressista. 
De forma analítica, a temática do poder em suas mais variadas acepções transcende a clássica preocupação com a divisão dos poderes de Montesquieu, alcançando as múltiplas perspectivas na visão de Marx (Dominação - Materialismo Histórico), Weber (Tipos Puros de Dominação, Tipos Ideais), Foucault (Microfísica do Poder e Vigiar e Punir), e as contribuições de Pierre Bourdieu (direito como sistema simbólico).

Na visão do Materialismo histórico, o poder se define pela dominação de classe. Para Marx é a posse ou a disposição dos meios de produção e a capacidade ou não de controlá-los que determina as possibilidades de exercício do poder por uma classe social. Sua concepção de poder político decorre daí, sendo o Estado, considerado no marxismo clássico, a instituição em virtude da qual uma classe dominante e exploradora impõe e defende seu poder e privilégios contra a classe ou classes que domina e explora.

$\mathrm{Na}$ proposta de Foucault, apesar de não estabelecer uma teoria geral sobre o poder, este se encontra de forma privilegiada em sua construção teórica. Para ele não há poder que designe alguma essência, existindo apenas relações de força que constituem situações de poder. O poder não pode ser circunscrito ou setorizado apenas ao econômico, pois seus mecanismos, efeitos, relações e dispositivos são exercidos em níveis diferentes da sociedade em domínios e, com extensão variada (FOUCAULT, 1979). Assim, a redução da questão do poder ao econômico, ao direito, ao Estado e seus aparelhos é empobrecer sua natureza. $\mathrm{Na}$ Microfísica do Poder, Foucault traz a concepção geral sobre o poder que pode ser vista como instrumento metodológico em todas as suas obras, sobretudo na História da Sexualidade (1976) e em Vigiar e Punir (2003) que traz seu ponto de vista do fenômeno da dominação. Deve-se considerar que Foucault tem outras matrizes à sua disposição, em especial, a teoria da dominação de Max Weber. Por isso sua concepção do poder é mais latente que patente e não admite concepções unívocas do poder. Foucault conseguiu ampliar o marxismo - mesmo sendo influenciado por este decisivamente -, para uma concepção mais lata dos elementos difusos do poder que não se reduzem apenas ao econômico. Por conseguinte, trata-se de (re)leitura de Marx, sob a problemática de Weber.

Em todas essas concepções, ainda que, em claro contraponto, o controle do poder é pressuposto da democracia, quer por razões de dominação na sociologia compreensiva de 
63

legalidade versus legitimidade (WEBER); por concepção inerente ao processo capitalista (MARX); por perspectivas mais abrangentes da discussão, qual seja, o tema do poder em sua acepção sutil (FOUCAULT); ou do direito na qualidade de sistema simbólico (BOURDIEU).

\section{DIREITO COMO SISTEMA DE DOMINAÇÃO}

Numa sociedade complexa cada vez mais sujeita ao fenômeno da judicialização da política e induzida ao descompasso dos poderes, parece urgente e necessária a afirmação da independência do Poder Judiciário no exercício da função jurisdicional. Um dos caminhos possíveis é o diagnóstico do processo pelo qual as circunstâncias se dão e, isso se encaixa na proposta metodológica de Pierre Bourdieu.

Pierre Bourdieu indica importante proposta na discussão do poder porque transcende qualquer reducionismo a categorias estritas e expande suas preocupações a estruturas (sistêmicas) e a agentes (sujeito). Seu tratamento incide sobre as configurações da aquisição e perpetuação do poder, trazendo uma contundente crítica às formas de produção científica, leia-se, os modelos de dominação como um todo, sendo impossível a separação de valores e representações. O resultado é o que importa e, nesse caso, não há concessões do poder. O que existem são apenas estratégias e investimentos de aquisição, acúmulo e perpetuação do capital simbólico (BOURDIEU, 1994; 2000).

Os conceitos fundamentais que servem de base para sua teoria são o campo e o habitus. O campo é estruturado pelas posições sociais derivadas de leis e regras próprias, ou seja, estrutura de relações objetivas derivadas do poder simbólico invisível e proveniente da cumplicidade entre os que o exercem e os que a ele se submetem; o habitus como conjunto de esquemas de classificação da realidade que se interiorizam pelos mais distintos processos estruturados e estruturantes relacionados às práticas e às regularidades de conduta. Conforme Bourdieu, campo é

A estrutura do campo é um estado da relação de força entre os agentes ou das instituições envolvidas na luta ou, se se preferir, da distribuição do capital específico que, acumulado no decorrer das lutas anteriores, orienta as estratégias posteriores. (2003, p. 120) [sic.] 
E habitus se constitui no,

O sistema de disposições adquiridas pela aprendizagem implícita ou explícita que funciona como um sistema de esquemas geradores, é gerador de estratégias que podem estar objectivamente em conformidade com os interesses objectivos dos seus autores sem terem sido expressamente concebidos para esse fim. (2003, p. 125) [sic]

Destarte, o campo é o espaço estruturado por posições onde dominantes e dominados lutam pela obtenção e manutenção de postos; e habitus é o lugar do sujeito em seus mais diversos modos de ação, condicionadas e orientadas a determinados fins.

O poder, o direito, o mercado, a sociedade, a ideologia, como outras formas de poder simbólico na condição de processos de dominação, funcionam de modo próprio e, em suas especificidades como modos de produção da coletividade operam numa sociedade concreta e determinada, existindo uma clara relação conducente na procura, produção e consumo de bens, incidindo numa relação transacional, qual seja, a produção de legalidade/legitimidade.

Pode-se inferir da estrutura judiciária, especialmente do STF, o ensejo de produção de bens simbólicos diretamente relacionados à estrutura social, com forte tendência à reprodução desta mesma conjuntura. Ela é altamente regulada pela estrutura interna do campo poder/Judiciário, que é ao mesmo tempo estruturado/estruturante. Estruturado porque determinado pelas relações de Estado e de poder; estruturante porque reproduz esses interesses com processo dominação.

Bourdieu ressalta o trabalho competente que o Estado, a Igreja, a escola, o mercado, o direito, dentre outros, exercem para garantir a perpetuação das relações de dominação. Do mesmo modo que as classes, a religião, a família, também o direito e seu órgão máximo deliberante, neste caso a cúpula judiciária, se serve de processos de dominação e legitimação (domínio das mentes).

Trata-se do "olho do poder" que não deve e nem pode ser excluído das discussões jurídicas, sob pena de desvio de finalidade. Além dele não se pode olvidar do poder originário 
65

do povo. Ambos exercem o controle do Estado, um controle que se impõe sempre, principalmente pela tendência de apropriação e abuso inerente à sua natureza.

Importante salientar que existe um conceito chave, o da violência simbólica, que permeia toda a estrutura do pensamento de Bourdieu, funcionando como elemento determinante, cimentar e equalizador das suas pesquisas. A violência simbólica é a própria concepção da realidade e seu funcionamento, haja vista sua subsistência a todas as suas outras concepções e, mesmo prescindindo delas, nunca o contrário.

Assim, a violência simbólica, além da dominação de classe que se perpetua pela ausência de emancipação e alienação dos bens de produção da classe trabalhadora, num sentido estritamente marxista (BOURDIEU, 2000), se define como:

(...) violência suave, insensível, invisível a suas próprias vítimas, que se exerce essencialmente pelas vias puramente simbólicas da comunicação e do conhecimento, ou, mais precisamente do desconhecimento, do reconhecimento ou, em última instância, do sentimento (BOURDIEU, 1999, p. 8-9).

Sua eficácia não depende apenas de estruturas objetivas, que no caso do direito seria facilmente detectável no elemento coação, mas também de estruturas cognitivas estruturadas e estruturantes. Ambas, por sua vez, se apropriam de símbolos para cumprirem a função de imposição e legitimação da dominação, assegurando a violência simbólica no interior do campo (BOURDIEU, 2000, p. 11).

Destaca-se que esse processo de dominação somente tem eficácia se o mesmo for acompanhado de sistemas ideológicos promovidos por especialistas que lutam pelo monopólio da produção ideológica legítima, a fim de estabelecer um discurso dominante estruturado e estruturante (ortodoxia) para a domesticação dos dominados (BOURDIEU, 2000, p. 11), que nada mais seria do que a sedimentação do habitus na padronização do pensamento ${ }^{7}$.

O Poder Judiciário se serve da violência simbólica com grande eficiência, uma vez que legitima seus atos por meio de princípios como o da legalidade e do Estado de Direito, elevados a Standards da justiça, ao mesmo tempo em que subtrai da sociedade - movimentos

7 Qualquer semelhança com “jurisprudência unificada” será mera coincidência. 
sociais, comunidades tradicionais, indígenas, quilombolas, redes socais, etc., - o direito/dever de promover a democracia participativa e $\operatorname{ativa}^{8}$, como no caso da delicada temática da reforma agrária.

No que se refere ao campo jurídico, Bourdieu encaminha sua proposta numa categorização da realidade a partir de tipos ideais determinados, dentre os quais o direito, sendo que, para ele:

A constituição do campo jurídico é um princípio de constituição da realidade (isto é, verdadeiro em relação a todo o campo). Entrar no jogo, conformar-se como o direito para resolver o conflito, é aceitar tacitamente a adopção de um modo de expressão e de discussão que implica a renúncia à violência física e às formas elementares da violência simbólica, como a injúria. É também, e, sobretudo, reconhecer as exigências específicas da construção jurídica do objecto: dado que os factos jurídicos são produto da construção jurídica (e não o inverso). (BOURDIEU, 2000, p. 229-230)

Deste modo, razoável é referir-se ao Estado/Judiciário como personificação/institucionalização do poder e, consequentemente, carecedor de controle democrático. Por isso periodicamente se discute a resistente e, ao mesmo tempo almejada democratização do Judiciário (BARBOSA, 2006; SADEK, 2003; 2006).

Trata-se aqui de democratizar não somente os processos internos, no que reconhecemos avanço com a inserção do CNJ - Conselho Nacional de Justiça ${ }^{9}$ e CNMP -

88 Essa oxigenação do poder necessita ser fortalecida pela democracia participativa e não pela contemplativa, mesmo em se tratando da transferência conveniente de responsabilidades da cidadania para o Ministério Público, como no caso brasileiro, que longe de contribuir para a democracia, produz efeito contrário e desastroso. Nem de longe, questiona-se aqui a tão importante atuação do Ministério Público nas mais diversas áreas, contudo, é preciso uma postura de convergência de interesses, não transferência ou concorrência, especialmente nas questões do meio ambiente, direitos humanos e cidadania. A omissão da sociedade civil brasileira tem lançado o Ministério Público à condição de alvo útil das mais diversas investidas daqueles que têm maior interesse em sua intimidação e limitação.

99 Iniciativas recentes do CNJ demonstram uma maior valorização de diagnósticos sobre o funcionamento, estrutura e importância do Judiciário, não apenas visando análises, mas, sobretudo, melhoria de seu papel e natureza como um todo. No entanto é preciso olhar atento ao momento por que passa o CNJ naquilo que podemos chamar de crise de identidade. Diante das declarações da corregedora Eliana Calmon sobre a existência de "bandidos de toga" no Judiciário, o CNJ, pressionado pelo então presidente do STF à ocasião, 
67

Conselho Nacional do Ministério Público, mas, designadamente, a própria composição, se não do juízo singular, por nossa enrijecida tradição, dos Tribunais, e em especial dos Tribunais Superiores e da cúpula do Judiciário brasileiro, o Supremo Tribunal Federal, pedra de toque do Judiciário que, não estando sob a égide do processo democrático direto, padece de legitimidade.

Na mesma toada questiona-se o modelo de escolha dos magistrados de primeiro grau. Embora assentado no salutar processo republicano que assegura a impessoalidade, traz em seu bojo problemas no que se refere ao seu caráter democrático. Segundo BARBOSA (2008),

O concurso público a que tem acesso todos os graduados em direito, é um critério de seleção técnica, que busca garantir a excelência, superando mecanismos tradicionais de preenchimento de funções públicas, baseada em relações de conveniência, amizade ou parentesco. Para a realidade brasileira parece ser o meio mais justo e igualitário de acesso, porque seleciona com base no conhecimento demonstrado pelo candidato.

Há, no entanto, inúmeras imperfeições nesse processo, o que acaba por torná-lo viciado, no sentido de preferir sempre um determinado tipo de candidato que pareça mais adequado a cumprir uma função posta, que esconde as contradições da sociedade, e as discussões em torno do Poder Judiciário. Justiça para quê e para quem?

A par de questões éticas, deve-se levar em conta que os concursos costumam privilegiar conhecimentos técnicos, legais, positivos, desprezando a leitura histórica, o raciocínio sistemático, a lógica

Cezar Peluso, que claramente demonstrava pouco apreço ao CNJ, publicou nota repudiando as acusações e considerando-as levianas. Na realidade o que parece estar em voga é a própria competência do CNJ. O então ministro Cesar Peluso, combinando com a opinião prevalente da AMB (Associação dos Magistrados do Brasil), defendia a concentração das investigações sobre os magistrados nas corregedorias dos Tribunais dos Estados, o que enfraqueceria o CNJ. A AMB propôs ADIn no STF objetivando tirar os poderes do CNJ de punir os magistrados por má conduta. 
dialética, uma análise política da função judiciária, e também a prática profissional. (grifos nossos)

O modelo reproduz o sistema simbólico de dominação econômica, proporcionando a perpetuação de uma casta de iniciados, como indica Bourdieu,

(...) e não pode ser de outro modo, porque o que está em jogo na luta interna pela autoridade científica no campo das ciências sociais, isto é,

o poder de produzir, impor e inculcar a representação legítima do mundo social, é o que está em jogo entre as classes no campo da política. (1994, p. 148) [sic] (grifos nossos)

\section{DEMOCRATIZAÇÃO DA FUNÇÃO JURISDICIONAL}

O que se coloca é o constante risco da independência dos poderes na democracia brasileira e, de forma imperiosa, a necessidade de legitimidade do STF como Tribunal Constitucional, para não dizer da própria instituição judiciária e Constituição ${ }^{10}$. Aquele, pelas razões de escolha política nem sempre éticas de seus membros, mormente desprezando outros critérios técnicos; esta, por padecer de um hermeneuta hercúleo, com advertia Dworkin (1999). Em ambos os casos, o princípio da suspeição e impedimento, assim como o da razoabilidade, passam de largo, posto que as escolhas podem ser pessoais e compadrias e o objeto demandado, em sua esmagadora maioria têm no polo passivo ou ativo o Poder Executivo.

Destarte, o principal mote aqui focado é a perspectiva da Jurisdição Constitucional como defesa do Estado Democrático de Direito, recorrente questão da finalidade do Estado, e, no caso em apreço, das ações do Judiciário no exercício da democracia que se dão por meio da Justiça Constitucional (ZAGREBELSKY, 2007).

\footnotetext{
${ }^{10}$ A Constituição Brasileira, apesar das constantes e efusivas exaltações à condição de cidadã, democrática, etc., carece de originalidade democrática. Não entraremos na discussão da legitimidade do Congresso Nacional que elaborou a Constituição de 1988 por fugir aos objetivos deste trabalho, mas deve-se considerar que, para elaboração de uma Constituição, em sua melhor lavra, somos da opinião de um congresso exclusivo e, portanto, constituinte em sua essência e não congresso constituinte como o caso da elaboração da Constituição de 1988, isso sem levar em conta ser fruto direto do regime militar que proporcionou os poderes ao presidente José Sarney para autorizar sua instalação.
} 
De certa maneira, essa justiça constitucional vem se operacionalizando na denominada judicialização da política, contemplada pelo fortalecimento do Judiciário em decidir pela execução de políticas públicas que modifica o modelo conceitual de poder do Estado moderno tradicionalmente concentrado no Executivo e Legislativo. A judicialização seria, especialmente, resultado do processo de constitucionalização de direitos operados nas Cartas constitucionais do pós-guerra, agasalhados por uma leitura moral da Constituição e uma teoria constitucional que lhe sustenta (BARBOSA e PAMPLONA, 2009).

Numa sociedade injusta, reflexo de um longo processo autoritário como a brasileira, excetuando alguns poucos períodos democráticos, concebida e representada numa distribuição de renda baseada na propriedade absoluta e burguesa ${ }^{11}$ (MARÉS, 2003), sob os efeitos de uma educação elitista que proporciona pouquíssima mobilidade social ${ }^{12}$ (BOTTOMORE, 1987) e, consequentemente, pouco acesso às profissões jurídicas mais bem remuneradas e detentoras do poder material e simbólico (TAVARES NETO e MEZZAROBA, 2007); insurge a relevância da Jurisdição Constitucional e sua prospecção de legitimidade, dado que incide exatamente sobre, e efeito de suas ações, a inquietante e emergente necessidade de justiça constitucional.

Mesmo considerando as origens autoritárias da Constituição Brasileira de 1988 e seu aspecto frankstenizado, fruto do esgotamento e desfiguração a que se sujeita pelo número excessivo de Emendas Constitucionais (TAVARES NETO, 2008), reconhece-se seus avanços na afirmação dos direitos fundamentais, ações coletivas, estabilização democrática, etc.. Mas seria obtusidade, no mínimo imprudência, atribuir-se ao Estado Constitucional os efeitos e benefícios dessas conquistas, que além de longe do alcance de uma democracia participativa e menos ainda racial, social e plural, não merece essa deferência, devendo ser atribuída às muitas expressões da sociedade em sua maturação democrática.

\footnotetext{
111 Essa temática continua espinhosa no âmbito do constitucionalismo, sobretudo no que tange a concepção burguesa de propriedade exarada no sistema brasileiro, que, mesmo protocolarmente indicando a função social da razão para mantença da propriedade, reproduz a falácia da desapropriação sem maiores penalidades, uma vez que a finalidade legal continua sendo a reprodução do sistema burguês.

112 Por isso a importância de políticas afirmativas de promoção de inclusão.
} 
Em suma, o direito não é democrático em sua concepção fundacional, muito ao contrário, altamente reacionário e perpetuador dos interesses dominantes, estando na sociedade civil organizada a responsabilidade e méritos pelos ainda tímidas mas graduais avanços democráticos conquistados na atual conjuntura. A legitimação da Constituição Brasileira é fruto, não da democratização do direito mas, ao contrário, timidamente do Estado em sua necessidade de sobrevivência, e da sociedade em especial, que se traveste de novas indumentárias nunca dantes vista - ONGs, Movimentos Sociais, Terceiro Setor, organização da sociedade, etc..

De certa forma, temos uma grande contradição em causa. Se por um lado o Poder Judiciário resiste bravamente a mudanças significativas em seu ethos decisório moroso e elitista, de outro percebe-se uma mudança expressiva na sociedade, fruto da alteração da tradicional contraposição eixo público versus privado para uma perspectiva mais interacional, podendo implicar numa (re)definição dos tradicionais conceitos estanques para uma nova ordem no campo dos direitos e das correspondentes tutelas coletivas.

Atualmente percebe-se a necessidade de consecução de políticas públicas que sejam de Estado e não mais de Governo e possam ser concebidas, formuladas e implantadas em consequência de consensos sociais forjados na participação efetiva da sociedade, e não mais definidas individualmente em decisões judiciais. Por isso a grande evidência do crescimento das políticas coletivas, especialmente no que se refere ao meio ambiente, cidadania, defesa do consumidor, etc.. São "Novas Práticas Coletivas" (MONTOVANELI JUNIOR, 2006, p. 31), ou novas formas de solidariedade e uma nova concepção da esfera pública, especialmente pela contribuição dos Movimentos Sociais, Terceiro Setor, Sociedade Civil organizada na construção dessa emergente consciência pública.

Mas como confiar na Justiça Constitucional realizada por uma Corte parcial, considerando-se sua forma de composição e os reflexos que se evidenciam em seus julgados ${ }^{13}$. Emblemáticos casos de nomeações ainda suscitam a contraditória interferência, para não dizer

${ }^{13} \mathrm{O}$ julgamento da Lei da Ficha Limpa demonstra essa contradição. A democracia desejando uma coisa e o STF julgando de forma diversa. Houve um empate no julgamento inicial, mas no julgamento final em 23 de março de 2011, como voto do ministro Luiz Fux, recém chegado à corte, o STF entendeu que a aplicação da Lei deve ser apenas nas eleições municipais de 2012. 
"representatividade" do chefe do Executivo no STF (DALLARI, 2002). Fernando Henrique Cardoso nomeou ao STF Gilmar Mendes seu advogado-geral da União e Nelson Jobim ${ }^{14}$, seu ministro da Justiça, fato imitado pelo presidente Luiz Inácio Lula da Silva com a nomeação de José Antonio Dias Toffoli, advogado geral da União em sua gestão. Discussões à parte da qualificação de ambos para a função e as eventuais prerrogativas políticas que sublinham suas trajetórias, é flagrante a necessidade de reflexão sobre a desmoralização do processo de escolha dos ministros do STF e, por consequência os riscos de suas funções institucionais. Ironicamente, Gilmar Mendes apressou-se em defender a nomeação de Toffoli, quem sabe por razões psicanalíticas ${ }^{1516}$. Os modelos aparentemente tão diferentes de FHC e Lula se aproximam no momento de proteção e perpetuação do sistema ${ }^{17}$. Kafka, em Metamorfose (2000), ficaria corado, para não dizer conformado com sua prescrição e extensão literária.

Se o processo de escolha dos Ministros não é democrático, menos ainda o é a forma de decidir daqueles que tem em suas mãos o poder de interpretar a Constituição e, por seu meio, delimitar direitos que afetam a sociedade com um todo. Não se pode dizer que os

114 Jobim foi ministro da Justiça de 1995 a 1997 no governo de Fernando Henrique Cardoso. Da Justiça foi para o Supremo Tribunal Federal, corte que presidiu de 2004 a 2005. Antes, de 2001 a 2003, presidiu o Tribunal Superior Eleitoral. A relação ambivalente de Jobim com o ex-presidente Fernando Henrique Cardoso custoulhe o ministério da defesa no governo Dilma.

115 Recentemente foi indeferido pedido de impeachment do ministro Gilmar Mendes tanto no Senado como em mandado de segurança no STF.

116 Outra questão envolvendo o ministro Gilmar Mendes, foi o questionável Habeas Corpus 102.098 concedido a Roger Abdelmassih em 23 de dezembro de 2009. Roger Abdelmassih, médico condenado a 278 anos por violentar 37 mulheres, fugiu do Brasil para o Líbano.

117 Dos atuais Ministros do STF, Celso Mello foi nomeado por José Sarney em 1989 podendo ficar até 2015; Marco Aurélio de Mello por Fernando Collor em 1990, podendo ficar até 2016; Ellen Gracie Northfleet nomeada em 2000, podendo ficar até 2018 e Gilmar Mendes nomeado em 2002, podendo ficar até 2025 , ambos nomeados por Fernando Henrique; Nomeados por Lula: Antônio Cezar Pelluso, nomeado em 2003 podendo ficar até 2012; Carlos Ayres Britto, nomeado em $\underline{2003}$ podendo ficar até 2012; $\underline{\text { Joaquim }}$ Barbosa nomeado em podendo ficar até 2024; Eros Grau nomeado em 2004, aposentado em agosto de 2010; Enrique Ricardo Lewandowski nomeado em 2006 podendo ficar até 2018; Cármen Lúcia Antunes

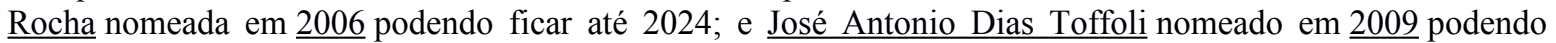
ficar até 2037. Luiz Fux (57 anos) em 03/03/2011 - primeiro nomeado pela Presidenta Dilma e ficará no posto até 2024 (Fux sempre defendeu um mandato de 10 anos para os ministros do STF - Veremos agora como se posiciona); Rosa Maria Weber Candiota da Rosa, nomeada em 9 de novembro de 2011 e ficará no cargo até 2018; e finalmente Teori Albino Zavascki, que já foi aprovado no Senado Federal no último dia 30/10/2012, indicado para ocupar uma vaga no STF, poderá ficar no STF até 2018. 
Ministros do Supremo Tribunal Federal componham um Corte única. Existem ali 11 magistrados, cada um compreendendo a seu próprio modo a realidade e os autos que os cercam. Eles decidem individualmente, em seus gabinetes, e suas decisões são compartilhadas apenas, quando são, com seus assessores. Logicamente podem convencer-se a argumentos diferentes apresentados pelos integrantes da Corte nas sessões de julgamento, mas esse convencimento é também em si mesmo um processo individual.

Ao contrário do processo de tomada de decisão que caracteriza momentos importantes da Suprema Corte norte-americana, no Brasil podem por vezes existir 11 votos, com fundamentos jurídicos e resultados diversos sobre um único caso. A jurisprudência não se firma por ser a posição da Corte, mas por ter sido aquele no momento o Acórdão vencedor.

Por isso espasmos de independência de um ou outro Ministro infelizmente não marcam a Corte. São, antes, individuais e não afastam a dúvida, muito antes a confirma, sobre os descaminhos por que passam a indicação e nomeação de Ministros.

Em um o outro caso, há uma armadilha ladeando a Corte que compromete sua própria legitimidade. Se for legítimo duvidar-se do processo de escolha e do processo de tomada de decisão, toda e qualquer decisão poderá ser posta em cheque. O mesmo raciocínio que fundamenta a desconfiança no Supremo Tribunal Federal em razão da decisão sobre a Lei da Anistia, que é citada mais adiante, sustenta também o recente julgamento do chamado Mensalão. Naquele caso pareceu evidenciada a parceria entre Executivo (à época chefiado pelo então presidente Lula) e Judiciário; neste parece ter restado evidente a ruptura da Corte com o Governo Lula.

No primeiro poder-se-ia aventar que a decisão está maculada pela excessiva proximidade e, em alguns casos, subserviência e gratidão, de Ministros para com o Governo; no segundo estaria maculada pela excessiva necessidade de mostrarem-se independentes, seja por pressão da sociedade que busca um justiceiro; da mídia nativa, cada vez mais parcial, mentirosa, irresponsável e por vezes criminosa na forma como obtém, modifica ou esconde informações, seja da própria necessidade de firmarem sua independência, apesar do Governo que os nomeou. 
No espetáculo midiático em que se transformou o Mensalão a condenação, aplaudida sem restrições pela mídia hegemônica, se deu muito mais por pressão social do que por princípios jurídicos constitucionalmente consagrados. Mesmo que para a condenação de alguns do réus tenha sido necessário decidir contra a prova do autos ou inferir provas inexistentes, alterar entendimento até então pacífico no jurisprudência da Corte e criar doutrina "inovadora". Parte dos Ministros preferiu, num jargão futebolístico que é familiar aos amantes do futebol, jogar pra torcida, ainda que o gol possa ter sido feito com a mão ou, no mínimo, com algum jogador impedido, contrariando as regras do jogo que também, como aferiria Bourdieu, não é democrático.

No anseio de se mostrar-se independente, o STF virou refém da mídia brasileira. Contudo, tivesse sido outra a decisão no caso do Mensalão ou no processo que considerou constitucional a Lei da Anistia, ainda assim a decisão da Corte poderia estar manchada. Porque, ao final, não se acredita no processo de escolha dos Ministros e, portanto, sempre será possível desconfiar-se decisão.

O argumento principal do texto, e que fique claro, não está na discussão da dignidade dos ministros nomeados ao STF e demais tribunais, ainda que essa temática mereça olhar atento da sociedade vez que o procedimento, porque legal, implica em responsabilidade objetiva de quem indica e aprova $^{18}$, mas na necessidade de compreensão do fenômeno jurídico brasileiro, qual seja a contaminação do sistema jurisdicional numa prospecção autopoietica ${ }^{19}$.

Trata-se de democratizar não somente os processos internos, mas a própria composição, se não do juízo singular, dos Tribunais e, em especial dos Tribunais Superiores. Este é o ponto nevrálgico do Judiciário, que não estando sob a égide de processo democrático direto, carece de legitimidade sistêmica, visto que não poucas vezes se autoregula e legitima

118 Art. 101 da Constituição Federal de 1988. O Supremo Tribunal Federal compõe-se de onze Ministros, escolhidos dentre cidadãos com mais de trinta e cinco e menos de sessenta anos de idade, de notável saber jurídico e reputação libada. Parágrafo único. Os Ministros do Supremo Tribunal Federal serão nomeados pelo Presidente da República, depois de aprovada a escolha pela maioria absoluta do Senado Federal.

119 Referimos a Niklas Luhmann, que no sistema autopoiético entende os seres como auto-referenciais e autoreprodutivos, e, desta forma, seu olhar sobre realidade se condiciona à própria dimensão de mundo; o Estado, na condição de expressão de representatividade deve ser reflexo do olhar da sociedade, sob pena de perder sua essência. 
(BOURDIEU, 2000). Como indica Barbosa (2006, p. 14), “a maior fraqueza do Judiciário está na fragilidade de sua legitimação. A sociedade não o conhece, não sabe como atua, considera-o ineficaz e percebe toda sua especificidade como um privilégio desmedido".

$\mathrm{O}$ voto que segue ilustra o modelo de magistrado que nem sempre todos querem, nem o próprio Judiciário, mas que continua a emergir como uma casta de equivocados, mas reprodutores do corpus jurídico (BOURDIEU, 2000). Em julgado do STJ (AgReg em ERESP $\mathrm{n}^{\circ}$ 279.889-AL), o Ministro Humberto Gomes de Barros ${ }^{20}$ assim se pronunciou:

Não me importa o que pensam os doutrinadores. Enquanto for ministro do Superior Tribunal de Justiça, assumo a autoridade da minha jurisdição. O pensamento daqueles que não são ministros deste Tribunal importa como orientação. A eles, porém, não me submeto. Interessa conhecer a doutrina de Barbosa Moreira ou Athos Carneiro. Decido, porém, conforme minha consciência. Precisamos estabelecer nossa autonomia intelectual, para que este Tribunal seja respeitado. É preciso consolidar o entendimento de que os Srs. ministros Francisco Peçanha Martins e Humberto Gomes de Barros decidem assim, porque pensam assim. E o STJ decide assim, porque a maioria de seus integrantes pensa como esses ministros. Esse é o pensamento do Superior Tribunal de Justiça e a doutrina que se amolde a ele. É fundamental expressarmos o que somos. Ninguém nos dá lições. Não somos aprendizes de ninguém. Quando viemos para este Tribunal, corajosamente assumimos a declaração de que temos notável saber jurídico - uma imposição da Constituição Federal. Pode não ser verdade. Em relação a mim, certamente, não é, mas, para efeitos constitucionais, minha investidura obriga-me a pensar que assim seja. (grifos nossos)

\footnotetext{
${ }^{2}{ }^{20} \mathrm{O}$ referido ministro foi eleito por unanimidade presidente do STJ em 06/03/2008, aos 69 anos de idade. Ficou na presidência do STJ de 07/04/2008 a 22/07/2008, data na qual se aposentou.
} 
Jurisdição implica em "dizer o direito", e nisso se consubstancia a essência da atividade jurisdicional, principalmente no controle concentrado de constitucionalidade exercido pelo STF. A necessidade de sua democratização é decorrência sistêmica dos efeitos da legitimidade das instituições, ainda mais em uma sociedade lamentavelmente pouco habituada ao pluralismo político/jurídico feito a brasileira. O que se depreende desse tipo de análise é que, sendo o Estado personificação/institucionalização do poder e, por conseguinte, carecedor de controle democrático, avoca-se a Jurisdição Constitucional na qualidade de instrumento de defesa do Estado Democrático de Direito. Contudo, tal propósito não se efetivará se o responsável por sua operacionalidade continuar alienado dos processos mínimos de inserção nessa realidade. Nesse campo, o do direito, existe um

corpus de textos que consagram a visão legítima, justa, do mundo social. É com essa condição que se podem dar as razões quer da autonomia relativa ao direito, quer do efeito propriamente simbólico do desconhecimento, que resulta da ilusão da sua autonomia absoluta em relação às questões externas. (BOURDIEU, 2000, p. 212)

Assim, a divergência entre os "intérpretes autorizados" são necessariamente limitadas e a coexistência de uma pluralidade de normas jurídicas concorrentes está excluída por definição da ordem jurídica. Como no texto religioso, filosófico ou literário, no texto jurídico está em jogo lutas, pois a leitura é uma maneira de apropriação simbólica que nele se encontra em estado potencial. (BOURDIEU, 2000, p. 213)

O campo do direito. "enquanto sistema de relações objetivas entre posições adquiridas, é o lugar, o espaço de jogo de uma luta concorrencial (...) o que está em jogo especificamente nessa luta é o monopólio da autoridade científica definida, de maneira inseparável, como capacidade técnica e poder social” (BOURDIEU, 1994, p. 121). Designadamente em seu sistema simbólico, existe uma valorização das funções em seus significados que se induz do modelo de dominação preponderante e resulta na produção de 
processos estruturados e estruturantes, o que Bourdieu denominou de habitus face sua regulação de condutas.

A maneira direta e contundente de Bourdieu indica o diapasão da proposta, uma vez que denomina

O campo científico, enquanto sistema de relações objetivas entre posições adquiridas (em lutas anteriores), é o lugar, o espaço de jogo de uma luta concorrencial. O que está em jogo especificamente nessa luta é o monopólio da autoridade científica definida, de maneira inseparável, como capacidade técnica e poder social; ou, se quisermos, o monopólio da competência científica, compreendida enquanto capacidade de falar e de agir legitimamente (isto é, de maneira autorizada e com autoridade), que é socialmente outorgada a um agente determinado. (BOURDIEU, 1994, p. 128)

Assim, a definição do que está em jogo na luta científica faz parte do jogo da luta científica: os dominantes são aqueles que conseguem impor uma definição da ciência segundo a qual a realização mais perfeita consiste em ter, ser e fazer aquilo que eles têm, são e fazem. Diga-se de passagem que a communis doctorum opinio (...). (BOURDIEU, 1994, p. 128)

O julgamento da ADPF 153 pelo STF indica o teor da preocupação bourdieusiana. A Ordem dos Advogados do Brasil por meio da ADPF contestava a Lei 6.683/1979 - Lei da Anistia e teve sua pretensão frustrada, tendo sido rejeitada por 7 votos a 2 pelo Pretório Excelso. A decisão, além de sua completa inconsistência pela imprescritibilidade dos crimes contra os direitos humanos, motivou profundas críticas das Nações Unidas, da Anistia Internacional e outras ONGs de Direitos Humanos, indicando a delicada relação entre poderes no campo político/jurídico brasileiro.

Para Bourdieu (1994), não seria bem uma relação delicada, mas precisamente a perpetuação do sistema simbólico que privilegia a forma estruturada e estruturante no cumprimento da 
(...) função política de instrumentos de imposição ou de legitimação da dominação, que contribuem para assegurar a dominação de uma classe sobre a outra (violência simbólica) dando o reforço da sua própria força às relações de força que as fundamentam e contribuindo, segundo a expressão de Weber, para a dominação dos dominados. (BOURDIEU, 2000, p. 11)

Pior, a completa destemperança entre bom senso e precaução, pelo menos em relação a muitas pessoas que tiveram seus familiares vitimados durante o regime militar de 1964. Não há justificativa institucional para o jantar de Ministros do STF com o presidente Lula no dia 28/10/2010, após o voto do relator, Ministro Eros Grau, no sentido de assegurar a constitucionalidade da referida Lei, voto este que se deu com o apoio também da Advocacia Geral da União e da Procuradoria Geral da República. Fica clara, pela análise proposta, a assimilação no universo do campo jurídico de uma racionalidade muito própria e sistêmica, que leva em conta muito mais sua própria autonomia e dinâmica interna (BOURDIEU, 2000, p. 209), sendo "capaz de produzir e de reproduzir, pela lógica do seu funcionamento específico, um corpus jurídico” (BOURDIEU, 2000, p. 210).

Por oportuno, não se deve olvidar que a proponente da ADPF, Ordem dos Advogados do Brasil, apoiou o Golpe de 1964, o que poderia indicar duas coisas: completa incoerência com sua trajetória e cumplicidade na ordem das coisas, ou, talvez, felizmente, que recobrou a consciência (ROLLEMBERG, 2008). Nesse sentido, bem nos esclarece Bourdieu (2000, p. 7.8), que “o poder simbólico é, com efeito, esse poder invisível o qual só pode ser exercido com a cumplicidade daqueles que não querem saber que lhe estão sujeitos ou mesmo que o exercem". (grifos nossos)

Eros Grau referiu-se à Lei da Anistia, como um "acordo histórico" e que a mesma "vem para pessoas indeterminadas, e não a determinadas pessoas". Para o ministro, a lei foi um grande acordo político que não pode ser revista, sendo que "A anistia seguramente foi bilateral", proclamou, durante seu voto.

Os efeitos da desastrada decisão do STF ainda não podem ser analisados com o distanciamento necessário, mas está a merecer profunda reflexão, especialmente após a 
condenação do Brasil na Corte Interamericana de Direitos Humanos ${ }^{21}$ pela detenção arbitrária, tortura e desaparecimento forçado de dezenas de pessoas em operações de repressão na Guerrilha do Araguaia durante a ditadura militar pós-golpe de $1964^{22}$, julgamento que firma jurisprudência contra o STF na CIDH e inaugura, em nossa concepção, um novo paradigma jurisprudencial na temática.

As assertivas de Bonavides indicam o tom da problemática a que se está sujeito nesta seara:

Se medidas não forem tomadas em tempo para coibir o abuso que tem conduzido a uma politização exagerada da justiça constitucional, a Suprema Corte correrá breve o risco de transformar-se numa sucursal, secretaria judiciária ou cartório do Poder Executivo, exercitando, em favor deste, a função normativa que as Cortes Constitucionais, quer queiram, quer não, têm exercitado, por via interpretativa, na ordem concreta dos fatos e da realidade, como uma espécie de legislativo paralelo e invisível. (BONAVIDES, 2004, p. 141)

Fora da esfera de um Direito Constitucional decadente e subjugado pela vontade presidencial, é de admitir, todavia, que num determinado sentido há, em rigor, duas Constituições paralelas: uma formal, outra jurisprudencial; a segunda, direito positivo concretizado, mais eficaz que a primeira porquanto sendo norma viva, solve os litígios constitucionais. E ao solvê-los, o Tribunal Constitucional mostra-se então fiador do Estado de Direito. Se decide bem, garante os direitos fundamentais. Se decide mal, dá um passo para a ditadura dos juízes. A pior das ditaduras é a tirania judicial personificada no governo da toga, nos magistrados da lei. Tirania sem remédio e sem retorno. Um

\footnotetext{
$2{ }^{21}$ Sentença de 24 de novembro de 2010.

222 O clamor dos Movimentos Sociais, ONU, Terceiro Setor, juristas, parentes das vítimas, não surtiu nenhum efeito sobre o voto dos Ministros do STF, parecendo confirmar a "independência" destacada pelo Ministro Humberto Gomes de Barros acima.
} 
Tribunal carente de independência, politizado ao excesso pelo Executivo, fragilizado pelo desrespeito à sua função, debilitado pelas omissões no controle jurisdicional de constitucionalidade é o inimigo da Constituição; (BONAVIDES, 2004, p. 141) (grifos nossos)

Dito de outra forma, um olhar sobre a atual e futura composição da Corte Constitucional brasileira, apoiada na previsão constitucional de indicação e nomeação do Presidente e aprovação quase que formal pelo Senado Federal, permite inferir uma migração a passos largos do STF de atividades idealizadas como garantistas da Constituição para garantidoras da legitimação (WEBER, 1991, 1993) dos atos do Executivo, que implica em um desvio de finalidade da Corte.

Encontra-se na proposta de Luigi Ferrajoli (2006) componente cimentar desta análise. Para Ferrajoli (2006, p. 16), “O estado constitucional de direito é a única ordem institucional em que é possível realizar o projeto garantista. Por meio dos vínculos substanciais da positivação do "dever ser" constitucional impõe-se ao próprio direito positivo". Ainda, "o garantismo necessita do constitucionalismo para fazer realidade seu programa ilustrado; e o constitucionalismo se alimenta do projeto garantista para condicionar a legitimidade do poder ao cumprimento de certas exigências morais que se condensam nos direitos fundamentais" (FERRAJOLI, 2006, p. 16).

Assim, a existência de um Estado Constitucional de Direito é essencial não somente no aspecto formal e material, mas também substancial para as condições de validez das normas, sendo que a validade está condicionada pela coerência de seus significados e conteúdos com os princípios constitucionais. A Jurisdição Constitucional se consubstancia de grande importância e significado nessa concepção garantista por ser a própria segurança do sistema o paradigma constitucional legitimatório. Nas palavras do autor,

O resultado tem sido uma definição da democracia constitucional como sistema jurídico articulado sobre duas dimensões: a dimensão formal, fundada no exercício dos direitos de autonomia, tanto política como civil; e a dimensão substancial, fundada sobre a tutela dos 
direitos de liberdade e a satisfação dos direitos sociais (FERRAJOLI, $2006,18)^{23}$.

Deste modo, o garantismo se funda na democracia e na acepção da Constituição como elemento primaz da representatividade, ou seja, "democracia constitucional", erigido sobre o Estado de Direito, na separação dos poderes, na Jurisdição Constitucional enquanto garantia do Estado Democrático de Direito.

O garantismo que propugna Ferrajoli é exatamente de compreensão inversa ao peleguismo ${ }^{24}$ observado no STF e que tem sua preocupação focada na necessidade de uma Corte Constitucional independente que possa garantir a efetividade da Constituição que, "no serve para representar la voluntad común de un pueblo, sino para garantizar los derechos de todos, inclusivo frente a la voluntad popular" (FERRAJOLI, 2003, p. 29). Numa palavra, o STF está necessitando de infusão na Constituição e mais imunidade contra a subserviência planaltina.

Também o chamado neoconstitucionalismo tem tentado enfrentar o tema. Advogando a relação necessária, e não mais contingente, entre direito e política, assim como a insurgência de valores morais que condicionam o processo jurídico decisório, busca a legitimação das Cortes na efetividade dos direitos constitucionalmente estabelecidos. E talvez esteja aí sua maior dificuldade para se afirmar como possível resposta às contradições e

${ }^{23}$ Garantismo é o nome dado ao conjunto de teorias a respeito do direito penal e processo penal, de inspiração juspositivista concebida pelo jusfilósofo italiano Luigi Ferrajoli, cuja obra maior sobre o assunto é "Direito e Razão". Significa algo como: "Estou protegido (garantido), pois está na lei (escrito/positivado)". Deste princípio surge o brocardo expresso no artigo $1^{\circ}$ do código penal brasileiro: Não há crime sem lei anterior que o defina. Não há pena sem prévia cominação legal. No entanto, o garantismo não se limita ao princípio da anterioridade da lei penal e ao direito positivo estrito. Tem como fundamento os princípios fundamentais do Direito: toda norma jurídica deve ser lida e interpretada na conformidade de seus princípios formadores e garantidores. Ele se serve da conscientização dos direitos do homem formulados em leis e pactos internacionais para reestabelecer a justiça mesmo contra a ordem positiva estrita.

${ }^{2}{ }^{24} \mathrm{O}$ termo peleguismo remete no Brasil à era getulista e à figura do pelego. Este "tinha por missão apresentar as medidas governamentais aos operários de um modo convincente. Para tanto invocava os interesses da nação. Em suma, o sentimento nacionalista tinha primazia sobre os interesses dos operários. Desde modo conseguia-se a paz social com a convivência da classe operária. Peleguismo. In Infopédia [Em linha]. Porto: Porto Editora, 2003-2012. [Consult. 2012-11-02]. Disponível na www: <URL: http://www.infopedia.pt/ \$peleguismo 
desgastes do constitucionalismo em sua concepção originária ideológica (COMANDUCCI in. CARBONEL, 2003, p. 82).

A despeito de seus caráter potencialmente inovador, é enorme a dificuldade em superar a capacidade sistêmica de reorganização dos processos de poder da antiga ordem constitucional centrada no positivismo, notadamente, pela afirmação do habitus que interioriza as mais diversas estratégias de regulação do status quo jurídico. Nesse sentido constatou Zagrebelski (2007) ser o maior desafio do neoconstitucionalismo a oferta de uma resposta eficaz ao desgastado regime do Estado de Direito pouco efetivo, mas, nomeadamente, o enfrentamento do poder em sua perpetuação de interesses dos dominantes pela instrumentalização da estrutura do campo jurídico para a transposição à justiça constitucional (ZAGREBELSKY, 2007).

A existência de mecanismos adequados e eficazes de controle de constitucionalidade é condição fundamental para a supremacia constitucional e segurança jurídica, essência do Estado moderno, mormente no Brasil. A concepção de Estado Democrático de Direito agasalhada na Constituição Brasileira é mais abrangente que o Estado de Direito consagrado nas constituições portuguesa de 1976 e espanhola de 1979, e assim o é também a jurisdição constitucional brasileira. Aqui espera-se mais do que a recorrente função jurisdicional de dizer o que é o direito em face da Constituição porque seu exercício exprime de fato o caráter hermenêutico condicionante principiológico da subordinação material aos direitos fundamentais. É um papel muito mais político que apenas agiganta a importância da legitimidade do processo de escolha dos Ministros, a busca de mecanismos que assegurem maior democratização da Corte e do processo de tomada de decisão que a caracteriza.

\section{CONSIDERAÇÕES FINAIS}

O exercício da função jurisdicional do STF no Brasil ultrapassa o simples arranjo institucional típico da divisão tripartite proposta por Montesquieu e deve ser analisado em uma perspectiva de poder.

A Jurisdição Constitucional se dá proferindo o que é o direito em conformidade com a Constituição. Dada a natureza atual das Constituições e os princípios que fundamentam o Estado Democrático de Direito, o único caminho possível é, parafraseando Luhmann 
(1969), sua legitimação pelo procedimento. Neste caso, o procedimento de escolha, nomeação e também o processo de tomada de decisão dos membros do Supremo Tribunal Federal. Não sem razão adverte Bonavides para o fato de que quanto mais perto do povo estiver o magistrado constitucional, mais elevado será o grau de sua legitimidade institucional e, consequentemente, suas ações confluirão para a credibilidade e segurança jurídicas (BONAVIDES, 2004, p. 132). O resultado será justo na medida em que antes do jogo se possa confiar no juiz.

Mas, é possível conciliar o controle de constitucionalidade num sistema induzido ao descompasso entre poderes e altamente favorável a persecução interferencial do Executivo com a realização da Constituição e a garantia do Estado Democrático de Direito? Bourdieu condicionaria tal possibilidade à alteração do habitus antidemocrático do Supremo Tribunal Federal que, perpetua e legitima a violência simbólica. As condições para que essa alteração possa se dar no campo necessariamente passa pela democratização do processo de escolha e de tomada de decisão, o que exige efetiva participação da sociedade e mecanismos de controle eficazes.

A nomeação antidemocrática é um vício de origem e por isso pode macular toda decisão. A necessidade de mostrar-se independente daquele que graciosamente os nomeou merece, no mínimo meditação terapêutica.

O retorno às origens, no caso em apreço, a Sófocles (2007), poderia contribuir para a reflexão sobre o poder e seus limites no âmbito do Estado Constitucional. Que Antígonas sejam necessárias, ninguém olvida; que elas prosperem, poucos se aventuram.

Foi bonita a festa pá,

Fiquei contente, inda guardo renitente um velho cravo para mim, Já murcharam tua festa, pá

Mas certamente

Esqueceram uma semente nalgum canto de jardim

Sei que a há léguas a nos separar, tanto mar, tanto mar

Sei também quanto é preciso, pá, navegar, navegar 
Canta primavera, pá, cá estou carente, manda novamente um algum cheirinho de alecrim

Chico Buarque de Holanda

\section{REFERÊNCIAS BIBLIOGRÁFICAS}

BARBOSA, Claudia Maria. Reflexões para um Judiciário socioambientalmente responsável. Revista da Faculdade de Direito da Universidade Federal do Paraná. Vol. 48. Curitiba, SER/UFPR, 2008.

; O processo de Legitimação do Poder Judiciário Brasileiro. In. XIV Congresso Nacional do $\overline{\text { CONPEDI }}$ - 2006, Fortaleza. Anais do XIV Congresso Nacional do CONPEDI. Florianópolis: Fundação Boiteux, 2006, v. 1.

BARBOSA, Claudia Maria e PAMPLONA, Danielle Anne. A judicialização da política e as audiências públicas no Supremo Tribunal Federal. In: Revista Paradigma. Ano X, no 18, jul/dez. 2009, p. 69-78.

BONAVIDES, Paulo. Jurisdição constitucional e legitimidade (algumas observações sobre o Brasil). Revista Estudos Avançados n ${ }^{\circ} 18$ (51), p. 127-50, 2004.

BOTTOMORE, T. B. Introdução à sociologia. Rio de Janeiro: LTC - Livros Técnicos e Científicos Editora S. A., 1987.

BOURDIEU, Pierre. Questões de sociologia. Lisboa: Fim de Século, 2003.

; O poder simbólico. Rio de Janeiro: Bertrand Brasil, 2000.

Ática, 1994.

; O campo científico. In. ORTIZ, Renato (org.) Pierre Bourdieu. Sociologia. São Paulo: Editora

CARBONELL, Miguel. Neoconstitucionalismo: elementos para una definición. In. MOREIRA, Eduardo Ribeiro (coord.). 20 anos da Constituição brasileira. São Paulo: Saraiva, 2009, p. 197-208.

; Teoría del neoconstitucionalismo. Madri: Totta, 2007.

COMANDUCCI, Paolo. Formas de(neo)constitucionalismo; un análises metateórico. In. CARBONEL, Miguel. Neoconstitucionalismo(s). Madri: Totta, 2003, p. 75-98.

DALlARI, Dalmo de Abreu. Degradação do Judiciário. Folha de São Paulo, São Paulo, 08 maio 2002. Tendências e debates.

DWORKIN, Ronald. O Império do direito. Tradução Jefferson Luiz Camargo. São Paulo, Martins Fontes, 1999.

FERRAJOLI, Luigi. Garantismo: uma discusión sobre Derecho y Democracia. Madri: Editorial Trotta, 2006.

; Pasado y futuro del Estado del Derecho. In. CARBONEL, Miguel. Neoconstitucionalismo(s). Madri: Totta, 2003, p. 13-29.

FOUCAULT, Michael. Microfísica do poder. Rio de janeiro: Edições Graal, 1979.

LUHMANN, Niklas. Legitimação pelo procedimento. Brasília, Ed. Universidade de Brasília, 1980.

MARÉS, Carlos Frederico. A função social da terra. Porto Alegre: Sérgio Antonio Fabris Editor, 2003.

MONTOVANELI JUNIOR, Oklinger. Políticas Públicas no século XXI: a perspectiva da gestão multicêntrica (à luz da experiência de Porto Alegre). Blumenau: Edifurd, 2006.

KAFKA, Franz. Metamorfose. São Paulo: Companhia das Letras, 2000. 
ROLlEMBERG, Denise. Memória, Opinião e Cultura Política. A Ordem dos Advogados do Brasil sob a Ditadura (1964-1974). In. REIS, Daniel Aarão; ROLLAND Denis. (Orgs.). Modernidades Alternativas. Rio de Janeiro: Ed. Fundação Getúlio Vargas, 2008, p. 57-96.

SADEK, Maria Tereza. Controle externo não resolve os problemas do Judiciário. Folha de São Paulo, São Paulo, 10 nov. 2003. Entrevista da 2., p. A-12.

; Magistrados: uma imagem em movimento. Rio de Janeiro: Editora FGV, 2006.

SÓFOCLES. Antígona. Lisboa: Fundação Calouste Gulbenkian, 2007.

TAVARES NETO, José Querino. Constituição e mercado: entre o débâcle e a (re)afirmação. Revista Sequência. Ano XXVII, nº 56, junho de 2008, p. 177-204.

TAVARESNETO, José Querino e MEZZAROBA, Orides. O espaço jurídico e suas relações de poder. Anais do Conpedi. http://conpedi.org/manaus/anais.php, ISBN: 978-85-87995-89-6. XVI Encontro do CONPEDI - Belo Horizonte, 2007.

WEBER, Max. Metodologia das Ciências Sociais. Tradução de Augustin Wenet, 2 a ed.. São Paulo: Cortez; Campinas: Editora da Universidade Estadual de Campinas, Parte 1, 1993.

; Economia e Sociedade. V. 1, trad. de Regis Barbosa e Karem Elsabe Barbosa, Revisão Técnica de Gabriel Cohn, Brasília: UnB, 1991.

ZAGREBELSKY, Gustave. El derecho dúctil. Madri: Editorial Trota, 2007.

Artigo recebido em 30 de abril de 2012 e aceito em 21 de junho de 2012. 